\title{
Microbial Diversity of Commercial Makgeolli and Its Influence on the Organoleptic Characteristics of Korean Rice Sourdough, Jeung-Pyun
}

\author{
Jaehyung Park ${ }^{1 \dagger}$, Ji Sun Seo ${ }^{2 \dagger}$, Seul-Ah Kim², So-Yeon Shin ${ }^{2}$, Jong-Hyun Park ${ }^{1 *}$, and Nam Soo Han ${ }^{2 *}$ \\ ${ }^{1}$ Department of Food Science and Biotechnology, Gachon University, Seongnam 13120, Republic of Korea \\ ${ }^{2}$ Brain Korea 21 Center for Bio-Resource Development, Division of Animal, Horticultural, and Food Sciences, Chungbuk National University, \\ Cheongju 28644, Republic of Korea
}

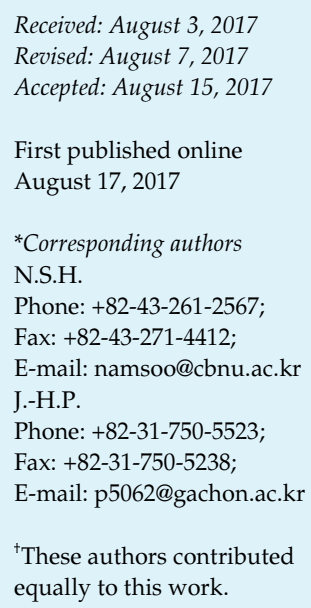

\begin{abstract}
Sourdough is made by fermentation of dough by lactic acid bacteria (LAB) and yeast to improve bread properties like volume, flavor, and texture. A Korean traditional sourdough was made by fermenting rice flour with rice wine (makgeolli) and used to make sponge-like bread (jeung-pyun). The aim of this study was to investigate the microbial diversity of makgeolli products and their influence on the organoleptic quality of jeung-pyun. Three commercial makgeolli were tested for jeung-pyun production, with each product exhibiting varied dough swelling rates and organoleptic qualities, and among them, J-product was ranked highest in texture and taste. Microbial analysis of the three makgeolli also showed a big difference in their population and diversity. J-product had the highest LAB and yeast counts, and the predominant species were Lactobacillus casei, Lactobacillus brevis, Leuconostoc pseudomenteroides, and Saccharomyces cerevisiae. Using J-product, sourdough was fermented at $25^{\circ} \mathrm{C}, 30^{\circ} \mathrm{C}$, and $35^{\circ} \mathrm{C}$, and the microbial growth in and textural properties of jeung-pyun were examined by instrumental and sensory tests. At high temperature $\left(35^{\circ} \mathrm{C}\right)$, the rates of dough swelling and acidification were fast due to rapid microbial growth mainly caused by LAB, resulting in a short leavening time and soft and sour jeung-pyun. Sensory tests showed consumer preference for the soft and mild-sour jeung-pyun. This study shows that LAB in makgeolli play key roles in production of jeung-pyun, influencing the textural and sensory properties. For the production of high-quality jeung-pyun, development of LAB starters with high gas productivity and low acidity and establishment of an optimal fermentation procedure for rice dough are necessary.
\end{abstract}

Keywords: Jeung-pyun, makgeolli, rice sourdough, yeast, lactic acid bacteria, fermentation

\section{Introduction}

Sourdough is a mixture of wheat or rice flour and water that is fermented by lactic acid bacteria (LAB) and yeast. The yeast generates gas to swell the dough, and the acids produced by LAB provide sour taste and flavor to the bread [1]. Sourdough fermentation has several advantages, such as formation of bread structure, enhancement of sensory and nutritional characteristics, increase in organic compound and mineral content, and reduction of blood glucose levels [2]. Additionally, it produces new nutritional compounds such as peptides and amino acid derivatives through microbial metabolism [3]. Liquid and dried sourdoughs are convenient to use in the industrial settings, and widely used in bakery industries [4].

Jeung-pyun is a rice bread made of rice flour and makgeolli (a traditional Korean rice wine) via fermentation and steam cooking. Considering the presence of LAB and yeast in makgeolli, Jeung-pyun is regarded a sourdough bread among different Korean rice cakes [5]. It has excellent storage characteristics due to its higher acidity compared with other kinds of rice cakes [6]. The preparation process for Jeung-pyun is similar to the direct kneading method in bread-making process; however, the dough is expanded by 
the $\mathrm{CO}_{2}$ produced by both yeast and LAB during the fermentation and the taste tends to be acidic owing to the organic acids produced by LAB. Jeung-pyun forms a network structure similar to that of bread, not made of wheat gluten, but of starches and dextrans synthesized by LAB $[7,8]$.

For bread-making, various commercial yeasts have been isolated and sold in a dried form, after characterization of their fermentation traits in wheat dough [9]. For sourdough fermentation, three different types of starters have been used, such as natural sourdough (Type I), Type II, and Type III. The natural sourdough uses back-slopping technology by inoculating current sourdough for the next batch. Type II uses liquid forms of starters of yeast and LAB, and Type III uses dried forms of starters [10]. Meanwhile, for Jeung-pyun production, the rice bakers in Korea use the commercial makgeolli as starter inoculums; however, the quality of Jeung-pyun varies depending on the makgeolli products (personal communication). Even though several previous works have investigated the LAB diversity in makgeolli $[5,11]$, their effects on fermentation and quality of Jeung-pyun have not yet been studied.

In this study, we investigated the microbial diversity of makgeolli products and their influence on the organoleptic quality of Jeung-pyun. For these experiments, we purchased three makgeolli products (J-rice wine, S-rice wine, and $\mathrm{N}$-rice wine) from local stores, and made Jeung-pyun after fermentation of rice dough by makgeolli. We also analyzed the influence of microbial diversity such as $\mathrm{LAB}$ and yeast in makgeolli, using both culture-dependent and cultureindependent methods. Furthermore, using the best makgeolli product, we analyzed the microbial growth and chemical changes during the fermentation period at various temperatures $\left(25^{\circ} \mathrm{C}, 30^{\circ} \mathrm{C}\right.$, and $\left.35^{\circ} \mathrm{C}\right)$ and investigated the textural and sensory changes of Jeung-pyun.

\section{Materials and Methods}

\section{Materials}

Rice flour (Nongshim, Korea), white sugar (100\% raw sugar; Cheiljedang, Korea), refined salt ( $\mathrm{NaCl}$ 99\%; Hanju Korea), and three makgeolli (J-, S-, and N-products) were purchased from the local markets.

\section{Preparation of Jeung-Pyun Using Commercial Makgeolli}

The conventional Jeung-pyun preparation process was modified in this study (Fig. 1). Jeung-pyun dough was prepared by mixing $100 \mathrm{~g}$ of rice powder, $30 \mathrm{ml}$ of commercial makgeolli (J-, S-, or Nproduct), $40 \mathrm{ml}$ of water, $250 \mathrm{~g}$ of sucrose, and $1 \mathrm{~g}$ of $\mathrm{NaCl}$. After degassing the first dough that was fermented for $3 \mathrm{~h}$ at $35^{\circ} \mathrm{C}$, the

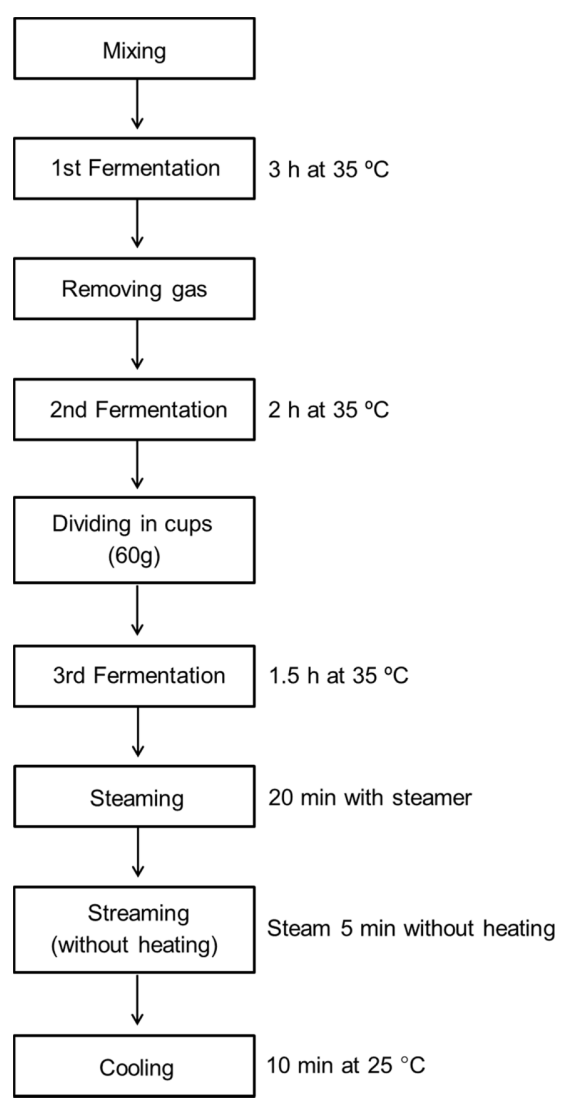

Fig. 1. Flow diagram of the preparation of Jeung-pyun.

second fermentation was continued for $2 \mathrm{~h}$ at the same temperature, using a dough conditioner (Hanbit Kitchen, Korea). The dough $(60 \mathrm{~g})$ was divided into stainless steel cups with upper horizontal diameter of $7 \mathrm{~cm}$, lower diameter of $5.5 \mathrm{~cm}$, and height of $4.5 \mathrm{~cm}$. The third fermentation was carried out for $1.5 \mathrm{~h}$, followed by 30-min steaming and additional 5-min steaming without heating, using Earthenware steamers (Daechang, Korea).

\section{Measurement of Volume Expansion of Dough}

Volume expansion of Jeung-pyun doughs supplemented with makgeolli at various fermentation temperatures was measured using a ruler. Dough samples ( $20 \mathrm{~g}$ ) were transferred to stainless steel cups and fermented for $18 \mathrm{~h}$ at $25^{\circ} \mathrm{C}, 30^{\circ} \mathrm{C}$, and $35^{\circ} \mathrm{C}$.

\section{Analysis of $\mathrm{pH}$ and Total Titratable Acidity}

Jeung-pyun doughs were fermented after inoculation of makgeolli at $25^{\circ} \mathrm{C}, 30^{\circ} \mathrm{C}$, and $35^{\circ} \mathrm{C}$ for $18 \mathrm{~h}$ and the $\mathrm{pH}$ was measured using a $\mathrm{pH}$ meter (iSTEK, Korea). Total titratable acidity (TTA) was measured by titration of a suspension consisting of dough samples $(10 \mathrm{~g})$ in distilled water $(90 \mathrm{ml})$ against $0.01 \mathrm{~N} \mathrm{NaOH}$ and was expressed as the percentage of lactic acid (AACC 2000).

\section{Microbial Analysis}

To count the number of LAB, each makgeolli was serially 
diluted with saline $(0.85 \%(\mathrm{w} / \mathrm{v}) \mathrm{NaCl})$ and plated on the bromocresol purple (BCP) plate count agar medium (Eiken Chemical Co., Japan). The BCP plate was incubated in an anaerobic culture jar with a gaspak (Becton, Dickinson \& Co., USA) at $35^{\circ} \mathrm{C}$ for $48 \mathrm{~h}$. For counting the number of yeast, each makgeolli was serially diluted with $0.85 \%$ saline solution and plated on YM agar (Becton, Dickinson \& Co.). The YM agar plate was incubated at $30^{\circ} \mathrm{C}$ for $24-48 \mathrm{~h}$.

Pyrosequencing analysis of three makgeolli was conducted at Macrogen Co., Ltd (Korea). Samples were prepared as described previously [12]. The modified PCR products were attached to DNA capture beads, and subsequently amplified using emulsionbased clonal amplification with appropriate chemicals and enzymes, and inserted into the Genome Sequencer FLX Titanium system (Roche, Germany) for pyrosequencing. All procedures were followed as per the manufacturer's protocols (Roche), and OTUs, Chao1, Shannon, Simpson, and Good's coverage were analyzed. Microorganisms present in each makgeolli were classified according to species using taxonomic assignment.

\section{Sensory Evaluation}

Sensory evaluations of the Jeung-pyun products were performed by 35 graduate students from the Department of Food Science and Biotechnology of Chungbuk National University. Each Jeungpyun preparation was cut into six equal-sized pieces and used for sensory evaluation. The Jeung-pyun samples were evaluated for acidic odor, sour flavor, hardness, texture, and overall acceptance on a 9-point scale. The mean and standard deviation of each evaluation item were calculated.

\section{Instrumental Texture Profile Analysis (TPA)}

Texture measurements were performed on two slices (20-mm thick), cut out from the central part of the Jeung-pyun after $4 \mathrm{~h}$ of cooking, and six measurements per slice were made. The Jeungpyun slices were compressed in the central area using a SMS P/35 flat probe (Stable Micro Systems, UK) to achieve 50\% deformation of the slice [13], with a waiting time of $30 \mathrm{sec}$ between the two bites [14]. An instrumental trigger of $0.05 \mathrm{~N}$ was applied. The following typical texture profile analysis parameters were determined from the force-distance curves and calculated by the software: hardness $(\mathrm{N})$, cohesiveness (adimensional), gumminess $(\mathrm{N})$, springiness $(\mathrm{mm})$, chewiness $(\mathrm{mJ})$, and resilience (adimensional) [15].

\section{Statistical Analysis}

All statistical analyses were performed with SAS ANOVA (SAS, USA). The significance of the mean value was tested by Duncan's multiple range test, considering $p<0.05$ as significant.

\section{Results}

\section{Quality Evaluation of Jeung-Pyun Made Using Commercial Makgeolli}

Jeung-pyuns were produced by steaming sourdoughs after fermentation using three makgeolli products, following the procedures described in Fig. 1. The physicochemical properties such as swelling height of dough and texture and sensory characteristics of Jeung-pyun were analyzed (Table 1). The order of swelling height of the sourdough was as $\mathrm{S}>\mathrm{J}>\mathrm{N}$, showing higher increases in S- and Jproducts $(4.13 \pm 0.12 \mathrm{~cm}$ and $3.60 \pm 0.30 \mathrm{~cm}$, respectively) compared with that in N-product $(2.23 \pm 0.15 \mathrm{~cm})$. In the texture analysis of Jeung-pyun samples, the order of hardness was $\mathrm{N}>\mathrm{J} \geq \mathrm{S}$, the order of springiness was $\mathrm{S} \geq \mathrm{J}$ $>\mathrm{N}$, and the order of resilience was $\mathrm{S} \geq \mathrm{J}>\mathrm{N}$. Since the hardness levels are reciprocal values representing "softness" in the TPA test of bread, addition of S- and Jmakgeolli in rice flour resulted in higher swelling during sourdough fermentation as well as a soft texture of Jeungpyun. In addition, the sensory test was performed on Jeung-pyun made using the commercial makgeolli to investigate the relationship between consumer's preference

Table 1. Results of the textural and sensory analyses of Jeung-pyun made of rice sourdoughs after fermentation by J-, S-, and Nmakgeolli products.

\begin{tabular}{llccc}
\hline & & & \multicolumn{2}{c}{ Makgeollis used for sourdough fermentation } \\
\cline { 2 - 4 } Objects and test parameters & $\mathrm{J}$ & $\mathrm{S}$ & $\mathrm{N}$ \\
\cline { 2 - 4 } Jeung-pyun & Height (cm) & $3.60 \pm 0.30^{\mathrm{b}}$ & $4.13 \pm 0.12^{\mathrm{a}}$ & $2.23 \pm 0.15^{\mathrm{c}}$ \\
(Texture & Hardness & $93.73 \pm 31.25^{\mathrm{b}}$ & $60.67 \pm 5.82^{\mathrm{b}}$ & $443.60 \pm 180.56^{\mathrm{a}}$ \\
analysis) & Springiness & $2.56 \pm 0.07^{\mathrm{a}}$ & $2.61 \pm 0.09^{\mathrm{a}}$ & $0.94 \pm 0.02^{\mathrm{b}}$ \\
Jeung-pyun & Resilience & $0.62 \pm 0.03^{\mathrm{a}}$ & $0.58 \pm 0.02^{\mathrm{a}}$ & $0.32 \pm 0.07^{\mathrm{b}}$ \\
(Sensory & Acidic odor (strength) & $4.56 \pm 1.91^{\mathrm{a}}$ & $6.09 \pm 1.83^{\mathrm{b}}$ & $4.25 \pm 2.02^{\mathrm{a}}$ \\
test) & Sour flavor (preference) & $5.82 \pm 2.14^{\mathrm{a}}$ & $4.11 \pm 1.25^{\mathrm{b}}$ & $5.37 \pm 1.80^{\mathrm{a}}$ \\
& Texture (preference) & $5.74 \pm 1.09^{\mathrm{a}}$ & $5.58 \pm 1.44^{\mathrm{a}}$ & $2.46 \pm 1.49^{\mathrm{b}}$ \\
& Overall acceptance & $5.53 \pm 1.32^{\mathrm{a}}$ & $4.17 \pm 1.27^{\mathrm{ab}}$ & $2.60 \pm 1.56^{\mathrm{b}}$ \\
\hline
\end{tabular}

${ }^{\mathrm{a}-\mathrm{c}}$ Mean \pm standard deviation, with different letters in the same line representing the difference by Turkey's test $(p \leq 0.05)$. 
Table 2. Microbial cell count (log CFU/ml) of three makgeolli products.

\begin{tabular}{lccc}
\multicolumn{1}{c}{ Products } & J-product & S-product & N-product \\
\hline Lactic acid bacteria & $7.25 \pm 0.11^{\mathrm{b}}$ & $7.87 \pm 0.11^{\mathrm{a}}$ & $6.53 \pm 0.11^{\mathrm{b}}$ \\
Yeast & $7.52 \pm 0.37^{\mathrm{a}}$ & $7.76 \pm 0.15^{\mathrm{a}}$ & $7.09 \pm 0.38^{\mathrm{a}}$ \\
\hline
\end{tabular}

Each value is the mean \pm SD. Different letters in a row indicate significant difference at $p<0.05$, as determined by Duncan's multiple range test.

and physicochemical properties of Jeung-pyun. Acidic odor represents the strength of acid scent and S-product scored the highest value $(6.09 \pm 1.83)$ whereas $\mathrm{N}$-product gave the lowest $(4.25 \pm 2.02)$. Meanwhile, the preference result for sour taste showed different patterns, with the best score $(5.82 \pm 2.14)$ for J-product, second $(5.37 \pm 1.80)$ place for N-product, and least ranking $(4.11 \pm 1.25)$ for Sproduct. The panels gave lower scores to both strong (S) as well as weak $(\mathrm{N})$ acidic odor; therefore, this result reveals the existence of an optimal concentration for organic acids in terms of consumer's preference, which holds true for Jproduct. The sensory test result on the textural preference of Jeung-pyun showed similar high scores for S- and Jproducts compared with the low score for N-product. Comparing this result with the TPA analysis of hardness, the consumers gave high scores to the breads with low hardness values (S- and J-products) and high swelling height (S- and J-products). The overall acceptance scores were the highest $(5.53 \pm 1.53)$ for J-product, second $(4.17 \pm 1.27)$ for S-product, and the lowest $(2.60 \pm 1.56)$ for $\mathrm{N}$-product. Even though S-product scored the highest in textural properties, it was ranked second owing to the strong acidic odor. Meanwhile, consumers preferred Jeung-pyun made using J-product that gave a good acidic flavor as well as soft texture.

\section{Microbial Analysis of Commercial Makgeolli}

The microbial populations of LAB and yeast in the commercial makgeolli were counted based on the colony forming units on the agar plate. As shown in Table 2, Sand J-products contained higher levels of microbial counts for both LAB and yeast: S-product had $7.87 \pm 0.11 \log$ $\mathrm{CFU} / \mathrm{ml}$ and $7.76 \pm 0.15 \log \mathrm{CFU} / \mathrm{ml}$, respectively, and $\mathrm{J}-$ product had $7.25 \pm 0.11 \log \mathrm{CFU} / \mathrm{ml}$ and $7.52 \pm 0.37 \log$ $\mathrm{CFU} / \mathrm{ml}$, respectively. Meanwhile, $\mathrm{N}$-product had low levels of microbial counts ( $\mathrm{LAB}$ and yeast) and they were $6.53 \pm 0.11 \log \mathrm{CFU} / \mathrm{ml}$ and $7.09 \pm 0.38 \log \mathrm{CFU} / \mathrm{ml}$, respectively. In S- and J-makgeolli, the population sizes of $\mathrm{LAB}$ and yeast were almost equivalent, showing equal dominance of both microbes in the products. In addition, the acidic odor strength observed in the sensory analysis in Table 1 showed consistent results in that the highest value $(6.09 \pm 1.83)$ in S-product was due to organic acids produced by the biggest population size $(7.87 \log \mathrm{CFU} / \mathrm{ml})$ of $\mathrm{LAB}$, and the lowest acidic odor strength $(4.25 \pm 2.02)$ in $\mathrm{N}$ product showed the smallest LAB size $(6.5 \mathrm{log} \mathrm{CFU} / \mathrm{ml})$. These results show that makgeolli is a rich source of microorganisms for fermentation of Jeung-pyun, and LAB in makgeolli play an important role for the quality of the product.

When the three makgeolli products were cultivated on YM medium, the yeast colonies showed similar morphology with respect to shape, size, and color. Three colonies were randomly picked from the medium and their 26S rRNA gene sequences were analyzed. The results showed that the sequences of three colonies were same and the colonies were identified as Saccharomyces cerevisiae. This result reveals that the makgeolli brewing companies use the same yeast starter strain.

On the contrary, the three makgeolli products showed different bacterial colonies on MRS medium, and the diversity indices of the microbial communities were calculated using pyrosequencing analysis based on $16 \mathrm{~S}$ rRNA gene sequencing reads. As shown in Table 3, the sequencing results of the three samples showed similar levels of Good coverage, but differing levels of clean reads $(\mathrm{J}>\mathrm{S}>\mathrm{N})$, OTU $(\mathrm{J}>\mathrm{S}>\mathrm{N})$, and Shannon-Weaver and Simpson indices $(\mathrm{S}>\mathrm{J}>\mathrm{N})$. The results show that $\mathrm{J}-$ product consists of diverse bacterial species with high OTU value, whereas S-product maintains uniformity in bacterial species (Shannon-Weaver) with limited diversity (Simpson).

Table 3. Statistical analysis of the barcoded pyrosequencing datasets obtained from three makgeolli products.

\begin{tabular}{cccccc}
\hline Sample name & Clean reads & OTUs & Shannon-Weaver & Simpson & Good's coverage \\
\hline J & 889 & 8.0 & 1.41 & 0.50 & 0.99 \\
S & 526 & 6.0 & 1.49 & 0.53 & 1.0 \\
N & 127 & 5.0 & 1.39 & 0.49 & 0.99
\end{tabular}

OTUs, operational taxonomic units; Shannon-Weaver, the number and evenness of species; Simpson, the probability that two randomly selected individuals in the habitat will belong to the same species; Good's coverage, a relative measure of how well the sample represents the larger environment. Diversity indices of the microbial communities were calculated using the RDP pyrosequencing pipeline based on the 16S rRNA gene sequencing reads. 
A

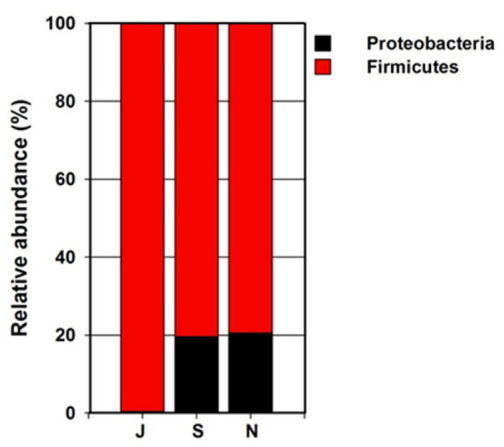

B

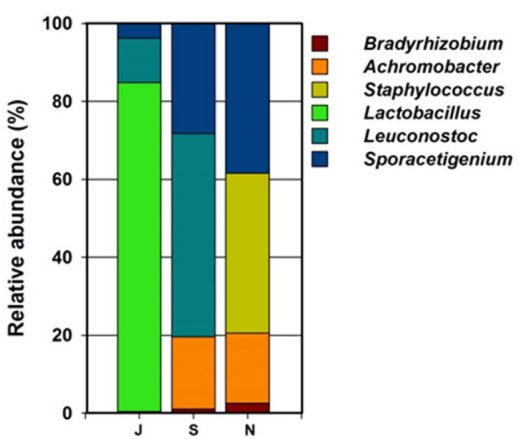

C

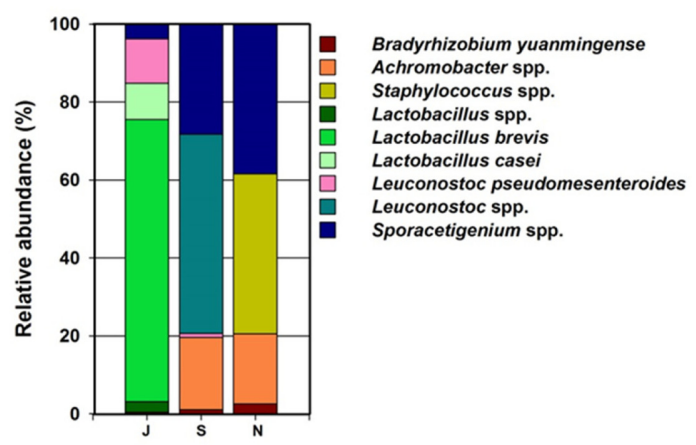

Fig. 2. Bacterial taxonomic compositions in J-, S-, and N-makgeolli products.

Data portray phylum- (A), genus- (B), and species- (C) levels of 16S rRNA pyrotagged gene sequences found in makgeolli products. The $16 \mathrm{~S}$ rRNA gene sequences with more than 300 bp were classified using the RDP naïve Bayesian rRNA Classifier at an $80 \%$ confidence threshold. The other categories in both panels are composed of phyla or genera, each showing a percentage of reads $<1.0 \%$ of the total reads in all of the samples.

Analysis of the sequencing results at the phylum level (Fig. 2A) revealed varying microbial compositions in the three products. Firmicutes were exclusively detected in the J-product, whereas $20 \%$ of Proteobacteria were present with Firmicutes in S- and N-products. In addition, when the results were compared at the genus level (Fig. 2B), in Jproduct, Lactobacillus $(\mathrm{Lb})$ spp. were dominant $(>80 \%)$ followed by Leuconostoc spp. and, in S-product, Leuconostoc (Le) spp. were dominant (>50\%) followed by Achromobacter and Sporecetigenium. Fig. $2 \mathrm{C}$ shows that J-product consists of Lb. casei, Lb. brevis, and Le. pseudomenteroides. Meanwhile, various bacteria other than $\mathrm{LAB}$ were mostly detected in $\mathrm{N}$ product, such as Bradyrhizobium yuanmingense, Achromobacter spp., Staphylococcus spp., and Sporacetigenium spp. In the previous studies, Lb. casei, Lb. brevis, and Le. pseudomenteroides were frequently detected in Korean makgeolli products and they were regarded as the major LAB species $[5,15-$ 17]. Our results reveal that the bacterial community in Jproduct has high similarity to that observed in previous studies.

\section{Fermentation Characteristics of Sourdough and Jeung- Pyun Made Using J-Makgeolli}

Since J-product was considered as the best inoculum to make high-quality Jeung-pyun by providing high and balanced levels of LAB and yeast, it was used for further experiments. After inoculation of J-makgeolli to the rice flour, we investigated the effect of temperature and time period on the growth of microorganisms, physicochemical properties of sourdough during fermentation, and sensory scores of Jeung-pyun (Fig. 3).

First, as shown in the top panel of Fig. 3, when microbial cell growth was measured during incubation of doughs at $25^{\circ} \mathrm{C}, 30^{\circ} \mathrm{C}$, and $35^{\circ} \mathrm{C}$, cell numbers of both $\mathrm{LAB}$ and yeast increased steadily until $18 \mathrm{~h}$ with different growth rates; comparatively, $\mathrm{LAB}$ and yeast grew faster at $35^{\circ} \mathrm{C}$ and $25^{\circ} \mathrm{C}$, respectively. This result shows that the population sizes of LAB and yeast can be readily controlled by adjusting the temperature during dough fermentation. In concordance with the previous result, during a fermentation period of $20 \mathrm{~h}, \mathrm{pH}$ values of the dough dropped to 4.6 at $25^{\circ} \mathrm{C}$ and to 4.0 at $35^{\circ} \mathrm{C}$, and the TTA values increased up to $0.20 \%$ at $25^{\circ} \mathrm{C}$ and $0.26 \%$ at $35^{\circ} \mathrm{C}$, indicating overproduction of organic acids by LAB at higher temperature. The physical changes of doughs were measured post incubation at different temperatures (center panel of Fig. 3). At $25^{\circ} \mathrm{C}$, the dough was swollen up to $12.5 \mathrm{~cm}$ after $6 \mathrm{~h}$; meanwhile, at $30^{\circ} \mathrm{C}$ and $35^{\circ} \mathrm{C}$, the doughs increased in volume to $12.5 \mathrm{~cm}$ after $12 \mathrm{~h}$. When the textural property of Jeung-pyun was measured after production by steaming the sourdough, the hardness level $(4,806 \pm 186,0 \mathrm{~h})$ at $25^{\circ} \mathrm{C}$ decreased to 650 after $6 \mathrm{~h}$ of fermentation and maintained the level thereafter, and at $35^{\circ} \mathrm{C}$ the level decreased steadily to $733 \pm 25$ after $6 \mathrm{~h}$ and gradually reached to $707 \pm 13$ after $12 \mathrm{~h}$. This result can be attributed to the differing growth rates (gas production rates) of LAB and yeast; yeast dominates in gas production at $25^{\circ} \mathrm{C}$, but yeast and $\mathrm{LAB}$ influence each other in gas production at $30^{\circ} \mathrm{C}$ and $35^{\circ} \mathrm{C}$. Furthermore, the sensory test was performed against Jeung-pyun samples made at different temperatures after 6 or $12 \mathrm{~h}$ (bottom panel of Fig. 3). For sour taste, the panels gave a high score $(6.92 \pm 1.32)$ to the sample made at $25^{\circ} \mathrm{C}$ after $6 \mathrm{~h}$, showing their preference for Jeung-pyun with lower contents of organic acids (high $\mathrm{pH}$ ). In the texture test, the panels gave 
A
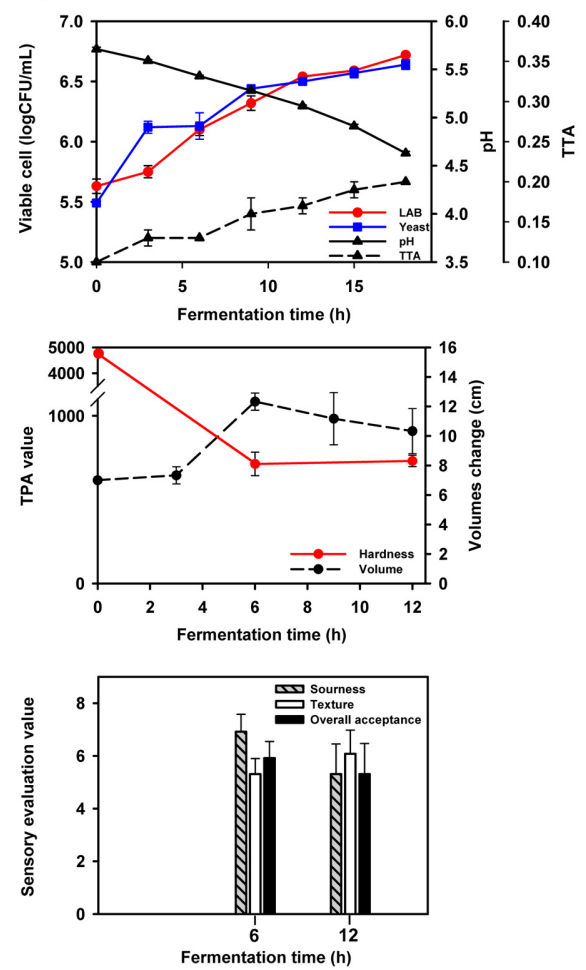

B
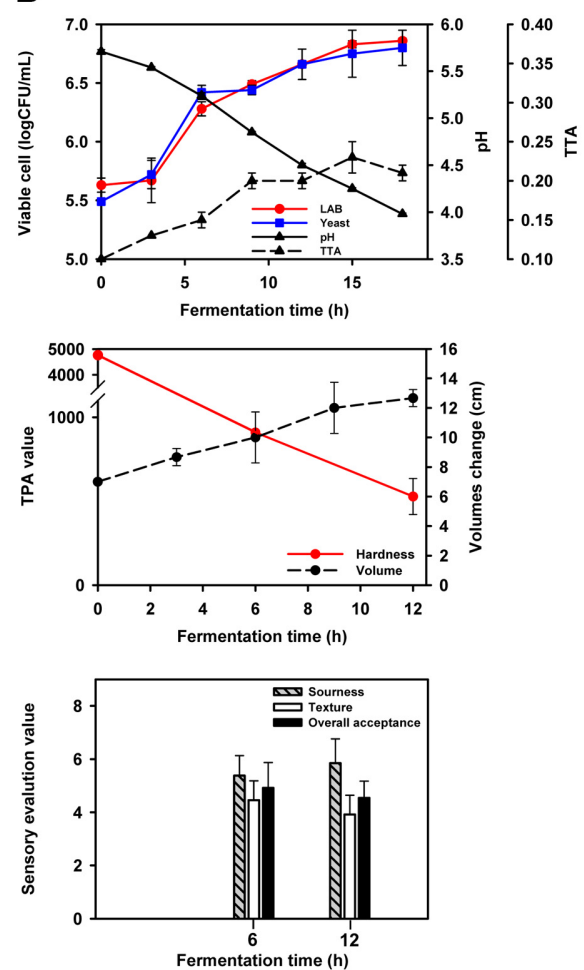

C
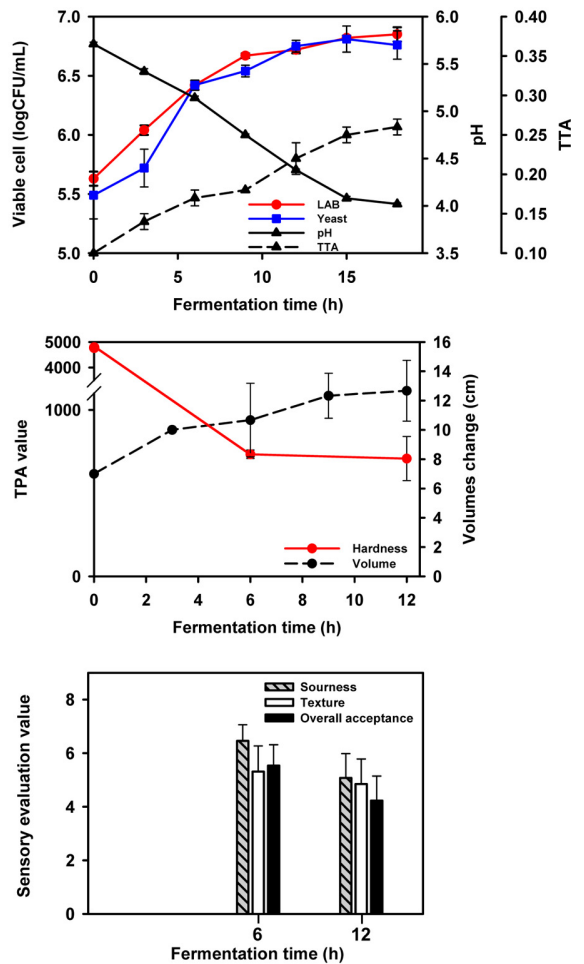

Fig. 3. Fermentation profiles, texture changes, and sensory results of Jeung-pyun made using sourdough after inoculation of Jmakgeolli product and fermentation at $25^{\circ} \mathrm{C}(\mathbf{A}), 30^{\circ} \mathrm{C}(\mathbf{B})$, and $35^{\circ} \mathrm{C}(\mathbf{C})$.

a high score $(6.08 \pm 1.80)$ to the sample made at $25^{\circ} \mathrm{C}$ after $12 \mathrm{~h}$; however, their preference for Jeung-pyun cannot be explained by comparison of their volume and hardness levels alone. Formation of big pores or color changes were also observed in the samples made at higher temperatures and they may influence the sensory test results. For more accurate textural analysis of Jeung-pyun, further experiments should be carried out to investigate the factors influencing formation of pores, their sizes, and color changes. For overall acceptance, the panels generally gave high scores to the Jeung-pyun having a soft texture and mild-sour taste. This result implies that dough fermentation should be carried out under the optimal condition (temperature and time period) to assure the preferred texture as well sensory characteristics by the co-cultivation of LAB and yeast.

\section{Discussion}

With an increase in the population representing aged people, it is necessary to develop tailor-made traditional foods for the elderly who are becoming major consumers of food. In addition, it is essential to develop products that can effectively increase the use of rice, which will meet nationwide needs for rice consumption in the current times. Therefore, in this study, we investigated the characteristics and quality of conventional Jeung-pyun dough supplemented with commercial rice wine and the quality of the Jeung-pyun products based on the microbial composition of makgeolli. Sourdoughs provide health benefits such as increased mineral bioavailability and a lower postprandial glucose response; however, allergies caused by wheat, barley, and rye glutens have led to increased public health awareness. Whereas wheat is the dominant cereal used for sourdough products throughout the world, rice is regarded as another cereal to produce sourdoughs because it is the main grain consumed in most Asian countries and no side effects have been reported so far for rice-based sourdoughs [18]. Jeung-pyun is considered as a potential traditional bread that is made using rice sourdough [19], and thus development of fermentation technology for Jeung-pyun as well as rice sourdough is of great necessity. Meeting this demand requires establishment of standard production methods of rice sourdough, and the quality of fermented products depends on the type of microbes involved in the fermentation.

When the dominant microbes were identified in the three 
commercial products, a single species of yeast, S. cerevisiae, was detected; however, the pyrosequencing results of the three makgeolli products showed the presence of varying bacterial communities among the products. The use of different makgeolli for sourdough fermentation resulted in varied dough swelling rates, affecting the textural property of the bread, and different concentrations of organic acids giving effect on the organoleptic qualities. This bacterial heterogeneity was possibly come from nuruk, which is a starter inoculum of makgeolli fermentation made by cultivation of microorganisms on the steamed wheat under open environmental condition [20]. Therefore, for production of high- and constant-quality Jeung-pyun, use of LAB starters as major bacterial inoculums are of great necessity.

Hence, analysis of the different microorganisms involved in the fermentation of sourdough is critical for the development of products in the food industry. In our results, various LAB strains were detected in the J-product, with lactobacilli being the dominating species $(>80 \%)$, including $\mathrm{Lb}$. casei and Lb. brevis, and Leuconostoc such as Le. pseudomenteroides. Lactobacillus species are the predominant LAB involved in sourdough fermentation. They include facultative or obligatory heterofermentative lactobacilli, such as $L b$. sanfranciscensis, Lb. plantarum, Lb.alimentarius, $L b$. pontis, $L b$. brevis, and $L b$. reuteri $[21,22]$. LAB are the predominant bacteria that initiate fermentation of cerealbased materials by producing $\mathrm{CO}_{2}$, organic acids, and exopolysaccharides such as dextran. They also produce several enzymes that help in hydrolyzing complex polysaccharides to simple sugars, thus modifying the environment and promoting the growth of other LAB belonging to different genera at later stages [23].

Wheat contains high amounts of proteins (11.3\%) compared with the chemical composition of rice $(7.7 \%)$, and gluten proteins such as glutenin and gliadin enable gas entrapment during yeast fermentation [24]. In the case of rice sourdough, to enable the dough swelling process, alternative compounds are necessary in place of gluten. Dextran is a microbial polysaccharide synthesized mainly by Leuconostoc spp. and it improves the bread volume and firmness and preserves freshness during storage [25]. Maltose present in rice dough can act as an acceptor molecule in the presence of sucrose, resulting in the formation of oligosaccharides. Moreover, since human digestive enzymes do not digest dextran and oligosaccharides produced during fermentation, they act as prebiotic compounds that benefit gut health [26].

Generally, sourdough contains a variable number of LAB and yeast, ranging from 7 to $9 \log \mathrm{CFU} / \mathrm{g}$ and 5 to $7 \log$
CFU/g, respectively, with a ratio of about 100:1 [27]. The main role of LAB (mainly obligate and facultative heterofermentative lactobacilli) is in the acidification process, whereas yeasts mainly account for the leavening of dough by releasing $\mathrm{CO}_{2}$ [28]. The fermentation temperature for sourdough is usually $27-37^{\circ} \mathrm{C}$ [29]; however, the condition varies depending on the application; mother sourdough is incubated at $25-28^{\circ} \mathrm{C}$ to get activated and refreshed. In our study, for the optimal fermentation condition with better sensory quality, panels gave the highest score to Jeung-pyun with a soft texture and mildsour taste, showing their preference for soft bread with lower contents of organic acids (high $\mathrm{pH}$ ). This result implies that fermenting dough at lower temperature assures the increased gas production by yeast and simultaneously avoids the overproduction of organic acids in sourdough by the co-cultivation of yeast and LAB. In this study, we investigated the effect of LAB and yeast on the quality of Jeung-pyun during dough fermentation. For the production of high-quality Jeung-pyun, development of LAB starters with high gas productivity and low acidity is necessary.

\section{Acknowledgments}

This work was supported by a grant (914002041SB) of Strategic Initiative for Microbiomes in Agriculture and Food funded by the Ministry of Agriculture, Food and Rural Affairs and a grant (2015R1A2A2A01007156) from the National Research Foundation of Korea (NRF) funded by the Korean Government (MEST).

\section{Conflict of Interest}

The authors have no financial conflicts of interest to declare.

\section{References}

1. Chavan RS, Chavan SR. 2011. Sourdough technology - a traditional way for wholesome foods: a review. Compr. Rev. Food Sci. Food Saf. 10: 169-182.

2. Katina K, Arendt E, Liukkonen KH, Autio K, Flander L, Poutanen K. 2005. Potential of sourdough for healthier cereal products. Trends Food Sci. Technol. 16: 104-112.

3. Gobbetti M, Rizzello CG, Di Cagno R, De Angelis M. 2014. How the sourdough may affect the functional features of leavened baked goods. Food Microbiol. 37: 30-40.

4. Minervini F, De Angelis M, Di Cagno R, Gobbetti M. 2014. Ecological parameters influencing microbial diversity and 
stability of traditional sourdough. Int. J. Food Microbiol. 171: 136-146.

5. Lim SB, Tingirikari JM, Kwon YW, Li L, Kim GE, Han NS. 2017. Polyphasic microbial analysis of traditional Korean jeung-pyun sourdough fermented with makgeolli. J. Microbiol. Biotechnol. 27: 226-233.

6. Lee EA, Woo KJ. 2002. Study on the dextran and the inner structure of jeung-pyun (Korea rice cake) on adding oligosaccharide. J. East Asian Soc. Diet. Life 12: 38-46.

7. Oh CH, Oh NS. 2009. Quality characteristics of jeung-pyun prepared by rice sourdough. J. Korean Soc. Food Sci. Nutr. 38: 1215-1221.

8. Lee AY, Park JY, Hahn YS. 2006. Study on the improvement of quality in jeung-pyun prepared with lactic bacteria having high dextransucrase activity as starters. Korean J. Food Sci. Technol. 38: 400-407.

9. Marongiu A, Zara G, Legras JL, Del Caro A, Mascia I, Fadda C, et al. 2015. Novel starters for old processes: use of Saccharomyces cerevisiae strains isolated from artisanal sourdough for craft beer production at a brewery scale. J. Ind. Microbiol. Biotechnol. 42: 85-92.

10. Corsetti A, Settanni L. 2007. Lactobacilli in sourdough fermentation. Food Res. Int. 40: 539-558.

11. Kim SY, Yoo KS, Kim JE, Kim JS, Jung JY, Jin Q, et al. 2010. Diversity analysis of lactic acid bacteria in Korean rice wine by culture independent method using PCR denaturing gradient gel electrophoresis. Food Sci. Biotechnol. 19: 749-755.

12. AACC. 2000. Titratable acidity, pp. 02-31. Approved Methods of the AACC, 10th Ed. American Association of Cereal Chemists, St. Paul, MN.

13. Kwon S, Kim TS, Yu GH, Jung JH, Park HD. 2010. Bacterial community composition and diversity of a full-scale integrated fixed-film activated sludge system as investigated by pyrosequencing. J. Microbiol. Biotechnol. 20: 1717-1723.

14. Wang J, Rosell CM, Benedito de Barber C. 2002. Effect of the addition of different fibres on wheat dough performance and bread quality. Food Chem. 79: 221-226.

15. Caballero PA, Gómez M, Rosell CM. 2007. Improvement of dough rheology, bread quality and bread shelf-life by enzymes combination. J. Food Eng. 81: 42-53.

16. Fik M, Surówka K. 2002. Effect of prebaking and frozen storage on the sensory quality and instrumental texture of bread. J. Sci. Food Agric. 82: 1268-1275.

17. Jin J, Kim SY, Jin Q, Eom HJ, Han NS. 2008. Diversity analysis of lactic acid bacteria in takju, Korean rice wine. J. Microbiol. Biotechnol. 18: 1678-1682.

18. Kim JY, Kim D, Park P, Kang H-I, Ryu EJ, Kim SM. 2011. Effects of storage temperature and time on the biogenic amine content and microflora in Korean turbid rice wine, makgeolli. Food Chem. 128: 87-92.

19. Awika JM. 2011. Major cereal grains production and use around the world, pp. 1-13. In Awika JM, Piironen V, Bean S (eds.). Advances in Cereal Science, Implications to Food Processing and Health Promotion. American Chemical Society, Washington, DC.

20. Seo DH, Jung JH, Kim HY, Kim YP, Ha SJ, Kim YC, et al. 2007. Identification of lactic acid bacteria involved in traditional Korean rice wine fermentation. Food Sci. Biotechnol. 16: 994-998.

21. Gobbetti M, Corsetti A, Rossi J. 1994. The sourdough microflora. Interactions between lactic acid bacteria and yeasts: metabolism of amino acids. World J. Microbiol. 10: 275-279.

22. Gobbetti M, Angelis DM, Corsetti A, Cagno DR. 2005. Biochemistry and physiology of sour dough lactic acid bacteria. Trends Food Sci. Technol. 16: 57-69.

23. Stiles ME, Holzapfel WH. 1997. Lactic acid bacteria of foods and their current taxonomy. Int. J. Food Microbiol. 36: 1-29.

24. Gobbetti M, Ganzle M. 2013. Handbook on Sourdough Biotechnology, pp. 12-13. Springer, Berlin-Heidelberg.

25. Cagno RD, Angelis MD, Limitone A, Minervini F, Carnevali P, Corsetti A, et al. 2006. Glucan and fructan production by sourdough Weissella cibaria and Lactobacillus plantarum. J. Agric. Food Chem. 54: 9873-9881.

26. Tingirikari JMR, Kothari D, Shukla R, Goyal A. 2014. Structural and biocompatibility properties of dextran from Weissella cibaria JAG8 as food additive. Int. J. Food Sci. Nutr. 65: 686-691.

27. Gobbetti M. 1998. The sourdough microflora: interactions of lactic acid bacteria and yeasts. Trends Food Sci. Technol. 9: 267-274.

28. Hammes WP, Ganzle MG. 1998. Sourdough breads and related products, Ch. 8. In Woods BJB (ed), Microbiology of Fermented Foods, 1st Ed. Blackie Academic, London. 